\title{
Economics of native poultry rearing in the coastal regions of Bangladesh
}

\author{
MT Uddin ${ }^{1}$ MM I slam², S Salam ${ }^{3}$, S Yasmin ${ }^{4}$
}

${ }^{1}$ Department of Agricultural Economics, Bangladesh Agricultural University, Mymensingh; ${ }^{2}$ FSR Division,

Bangladesh Livestock Research Institute, Savar; ${ }^{3}$ Institute of Agribusiness and Development Studies,

Bangladesh Agricultural University, Mymensingh; ${ }^{4}$ Buffalo Development Project, Bangladesh Livestock Research Institute, Savar, Dhaka, Bangladesh

\begin{abstract}
This study attempts to estimate the income from native poultry production and analyze the efficiency of resources used covering three coastal districts of Bangladesh namely Noakhali, Patuakhali and Satkhira. A total of 180 poultry rearers were selected from different villages of the districts using purposive sampling technique. Primary and secondary data were collected and analyzed following a combination of descriptive statistics, sensitivity analysis, statistical model and mathematical technique. Gross and net returns per household per day from native poultry rearing were estimated at Tk. 34.04 and Tk. 27.93 , respectively. The undiscounted benefit cost ratio was 5.57 , implying that this enterprise is highly profitable. Moreover, the contribution from poultry rearing to total income was 8.25 percent. Sensitivity analysis shows that the gross margins and benefit cost ratios were strongly influenced by the factors such as the cost of inputs, price of outputs and poultry inventory. Multiple Regression model revealed that almost all variables were influenced income from native poultry farming except rearing cost. Increasing returns to scale was found which indicates that there was bright prospect to earn more through the use of more inputs in the production process. Finally, a number of problems faced by the poultry farmers were identified and some suggestions were recommended accordingly.
\end{abstract}

Key words: Benefit cost ratio, native poultry, resource use efficiency, sensitivity analysis

Bangladesh Animal Husbandry Association. All rights reserved.

Bang. J. Anim. Sci. 2013. 42 (1): 49-56

\section{Introduction}

Poultry farming has emerged as one of the most flourishing and promising agribusiness avenue in Bangladesh. Though poultry farming was not considered as an important occupation in the past; in recent years, commercial poultry farming is getting more and more popularity in response to the wide market opportunity. It contributes significantly to the welfare of the population at both household and national levels by: meeting human needs for dietary animal supply; providing income to farmers through sale of meat and egg; using the by-product wastes of poultry as feed for the fish farming; expanding more job opportunities for the unemployed people and alleviating poverty in the shortest period of time. Overall, the annual average growth in poultry production from 2005 to 2011 was 3.7\% (BER 2011). This indicates an increasing demand for poultry products as a result of economic growth and higher income. The poultry population and its consequent output production are shown in Table 1. The Second Five Year Plan (SFYP) and Department of Livestock Services (DLS) projected the requirement and availability of livestock products up to 2021, where it was shown that egg production should be increased by $274 \%$ in the year 2013 and $114.9 \%$ in the year 2021 from the base line year 2008 (SFYP 2009). To achieve the projected demands for meat and eggs, strategic plans will have to be required to 1.5-1.8 times increase in the production in the years 2020 and 2030.

Table 1. Number of poultry birds and production of meat and egg in Bangladesh

\begin{tabular}{lccccc}
\hline & \multicolumn{2}{c}{$\begin{array}{c}\text { No. poultry birds } \\
\text { (Million) }\end{array}$} & \multicolumn{2}{c}{$\begin{array}{c}\text { Production of } \\
\text { meat and egg }\end{array}$} \\
\cline { 2 - 6 } Year & & & $\begin{array}{c}\text { Total } \\
\text { Poultry }\end{array}$ & $\begin{array}{c}\text { Meat } \\
\text { (Million } \\
\text { ton) }\end{array}$ & $\begin{array}{c}\text { Egg } \\
\text { (Million } \\
\text { no.) }\end{array}$ \\
\hline $2005-06$ & 194.82 & 38.17 & 232.99 & 1.13 & 5422 \\
$2006-07$ & 206.89 & 39.08 & 245.97 & 1.04 & 5369 \\
$2007-08$ & 212.40 & 39.84 & 252.31 & 1.04 & 5653 \\
$2008-09$ & 221.39 & 41.23 & 262.62 & 1.08 & 4692 \\
$2009-10$ & 228.03 & 42.67 & 270.71 & 1.26 & 5742 \\
$2010-11$ & 234.68 & 44.12 & 278.80 & 1.99 & 6079 \\
\hline
\end{tabular}

Source: BER 2011

In Bangladesh, over $30 \%$ of the net cultivable area is in the coastal region (Miah, 2010). Majority of the people in coastal areas are involved in crop cultivation, fishing and they remain frequently unemployed due to tidal flooding and other natural disasters which results 
food insecurity in the areas. But now-a-days, crop land are gradually converted into non-crop agriculture due to expansion of water-logged areas, expansion of shrimp culture, poultry farm, high market price of poultry, and so on. Poultry rearing is a supportive activity in the coastal areas and land involved in poultry farming have been increased 20 to 30 times more than the previous decades (Miah 2010). Besides, farmers in some parts of the coastal areas are also incorporating native poultry rearing on scavenging basis along with crop farming. Rahman et al. (2009) found that rearing of poultry gives maximum return with minimum cost. Moreover, poultry production in the coastal districts of Bangladesh provides self-employment for landless and small farmers, especially for women.

As poultry production provides maximum return with minimum expense, very small area of available land can be well utilized for poultry farming in a highly populated country like Bangladesh. Thus, it has a great prospect to swell poultry production in the country. Moreover, to improve poultry productivity and increase meat and egg production as well as availability of these products to the farm families, different types of native chickens are reared by the rural households in our country for subsistence purpose. Considering the fact, this study attempts to provide the information about the coefficients of income generated from native poultry rearing as well as the efficiency of resources used. Such information can be of good use by the policy makers in order to improve the overall livelihood status of rural poor small farmers. The overall objective of the study is therefore to estimate the income from poultry production and measure resource use efficiency of the relevant factors.

\section{Materials and Methods}

Study areas were selected from five Upazilas of three coastal districts namely Noakhali, Patuakhali and Satkhira. From each district, at least one Upazila was purposively selected as the study location considering the concentration of poultry rearing. The selected Upazilas were Hatia and Subornochar under Noakhali district, Kalapara under Patuakhali and Tala Upazila under Satkhira district. A total of 180 poultry farmers were interviewed for the collection of necessary data and information who were involved in native poultry rearing (60 farmers from each of the three districts). Purposive sampling technique was followed for selecting these respondents. Field survey method was followed to collect primary data for one year of operation. Data were collected from respondents by using semistructured interview schedule. Secondary data and information were also collected and discussed for this research from different handouts, reports, publications, notifications, etc. For analyzing the data, a combination of tabular and mathematical techniques were used to achieve the objectives and to get the meaningful results. In addition, sensitivity analysis was used to assess the effects of adverse changes of the relevant factors. The multiple regression model was used to determine the effects of key variables. To identify the most important variables of poultry rearing, the following specification of the model was made:

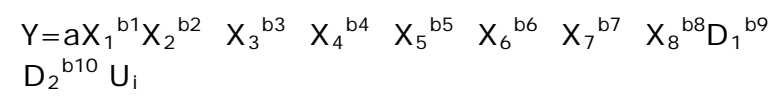

The model was transformed into following logarithmic form so that it could be estimated by the ordinary least squares (OLS) method:

$\ln Y=\ln a+b_{1} \ln X_{1}+b_{2} \ln X_{2}+b_{3} \ln X_{3}+b_{4}$ $\ln X_{4}+b_{5} \ln X_{5}+b_{6} \ln X_{6}+b_{7} \ln X_{7}+b_{8} \ln X_{8}+$ $b_{9} D_{1}+b_{10} D_{2}+U i$

Where,

$Y=$ Gross return (Tk. /Year); $X_{1}=$ Age of the respondents; $X_{2}=$ Year of schooling; $X_{3}=$ Family size; $X_{4}=$ Land holding; $X_{5}=$ No. of livestock enterprises; $X_{6}=$ Working hours; $X_{7}=$ Rearing cost; $X_{8}=$ Income from other sources; $D_{1}=$ Training; $D_{1}=1$ if training received by the farmers, $D_{1}=0$ otherwise; $D_{2}=$ Vaccine and medication; $D_{2}=1$ if vaccine and medication used by the farmers, $D_{2}=0$ otherwise; In = Natural logarithm; $a=$ Constant/intercept; $b_{1}$, $b_{2 . . .} b_{10}=$ Production coefficients of the respective variables; and Ui = Error term.

Moreover, mathematical technique i.e., marginal value product (MVP) and marginal factor cost (MFC) comparison was done to measure efficiency/inefficiency of the resources used in rearing poultry.

\section{Results and Discussions}

\section{Profile of the Respondents}

All the family members of respondents household were classified into four age groups. It can be seen from the Table 2 that average family size was estimated at 4.56 persons, comprising 2.49 males and 2.07 females which was higher than the national average (4.5) of the country (HIES, 2010). This fact quite reliably depicts the existence of population pressure among the 
poultry rearer groups in the study areas.

51 
Uddin et al. (2013) Bang. J. Anim. Sci. 42 (1): 49- 56

Table 2. Age distribution and family size of sampled poultry farmers' member

\begin{tabular}{lcccccc}
\hline \multirow{2}{*}{ Age group } & \multicolumn{3}{c}{ Male } & \multicolumn{2}{c}{ Female } & \multicolumn{2}{c}{ Both } \\
\cline { 2 - 7 } & No. & $\%$ & No. & $\%$ & No. & $\%$ \\
\hline Below 5.0 & 57 & 12.69 & 48 & 12.90 & 105 & 12.79 \\
$5.0-15.0$ & 97 & 21.60 & 90 & 24.19 & 187 & 22.78 \\
$15.01-55.0$ & 193 & 42.98 & 141 & 37.90 & 334 & 40.68 \\
Above 55.0 & 102 & 22.72 & 93 & 25.00 & 195 & 23.75 \\
All age group & 449 & 100.00 & 372 & 100.00 & 821 & 100.00 \\
Average family size & 2.49 & - & 2.07 & - & 4.56 & - \\
\hline
\end{tabular}

Source: Field survey 2012

In this study, farm size of poultry farmers was estimated by using the following formula:

Average farm size $=$ Homestead Area + Owned cultivable land + Rented/mortgaged/ leased-in + Area under pond + Pasture land - Rented/mortgaged/ leased-out land.

Table 3 reveals that about 17 and 53 percent of the respondents' total land was used as homestead area and cultivable land, respectively. It was also found from the survey that most of the male respondents (60\%) had agriculture as principal occupation. Poultry rearing was considered as supplementary activity for small farmers.

Table 3. Average land holding of poultry farmers according to utilization patterns

\begin{tabular}{lcc}
\hline Types of land & Area (ha) & Percentage \\
\hline $\begin{array}{l}\text { Homestead Area } \\
\text { Owned cultivable }\end{array}$ & 0.10 & 17.24 \\
land & 0.31 & 53.45 \\
$\begin{array}{l}\text { Rented/mortgaged } \\
\text { /leased-in land }\end{array}$ & 0.07 & 12.07 \\
$\begin{array}{l}\text { Rented/mortgaged } \\
\text { /leased-out land }\end{array}$ & 0.05 & 8.62 \\
$\begin{array}{l}\text { Area under pond } \\
\text { Pasture land }\end{array}$ & 0.02 & 3.45 \\
\hline Total & 0.03 & 5.17 \\
\hline
\end{tabular}

Source: Field survey 2012

\section{Profitability of rearing native poultry}

On the basis of full cost, per household per day cost of native poultry rearing was estimated at Tk. 6.11 and on the basis of variable cost estimation, this cost amounted to Tk. 5.79 (Table 4).

Interest on operating cost was charged at the rate of 12.00 percent per annum and was estimated for the duration of 12 months. This cost was Tk. 0.33. Gross returns and the net returns per day from poultry rearing were estimated at Tk. 34.04 and Tk. 27.93 respectively. The benefit cost ratio was 5.57, which indicates that poultry rearing was profitable in the study area. It is also revealed from the table that human labor costs comprised the highest percentages of total costs. Timely feeding and taking care are the most important efforts to increase poultry production and profitability.

\section{Employment generation through poultry rearing}

Both women and children are involved in poultry rearing especially, the women in rural areas are directly involved in home-based activities to strengthen income generation through poultry rearing.

All of the respondents equally admitted that women and children were mostly involved in poultry rearing. Women participants agreed that male counterparts had slightly less involvement in poultry rearing. It is revealed from table 5 that, on an average, male members spent about 3.10 hours a month on poultry rearing, while the female members spent 11.30 hours a month over the study regions. Average total working hours employed in poultry shed cleaning and taking poultry in and out were 5.16 and 4.77 hours a month, which constituted the highest working hours.

\section{Annual income of poultry rearing farmers}

Income sources were classified into three major categories, which are: farm income, non-farm income and income from other sources of income. Table 6 shows that the overall farm income was estimated at 83.23 percent for the sampled farmers. Contribution of crop farming was the highest to their farm income and it captured 33.58 percent of the total annual income. Moreover, income from poultry rearing is the third highest and its contribution to farmers' gross income was 8.25 percent. Many of the farmers were involved in agriculture labor selling, rickshaw pulling, small trading and attractive business. About 15.97 percent of the total annual income was contributed from the non-farm sources. Thus, poultry rearing could be sustainable avenue for employment creation, income generation and maintaining household expenditure. 


\section{Economics of native poultry rearing}

Table 4. Total costs and returns of native poultry rearing (Per household per day)

\begin{tabular}{|c|c|c|c|c|c|}
\hline Particulars & Unit & Quantity Used & Price/unit (Tk.) & Value (Tk.) & $\%$ of total \\
\hline A. Variable cost & & & & 5.79 & 94.76 \\
\hline a. Feed cost & & & & 2.91 & 47.63 \\
\hline i. Prepared feed & $\mathrm{Kg}$ & 0.01 & 32 & 0.36 & 5.89 \\
\hline ii. Rice grain & $\mathrm{Kg}$ & 0.10 & 18 & 1.73 & 28.31 \\
\hline iii. Wheat grain & $\mathrm{Kg}$ & 0.03 & 15 & 0.44 & 7.20 \\
\hline iv. Others & Tk. & & & 0.38 & 6.22 \\
\hline b. Veterinary cost & & & & 0.55 & 9.00 \\
\hline c. Water and electricity cost & & & & 0.03 & 0.49 \\
\hline d. Transportation cost & & & & 0.34 & 5.56 \\
\hline e. Labor & Man-days & 0.01 & 200 & 1.63 & 26.68 \\
\hline f. Interest on operating cost & & & & 0.33 & 5.40 \\
\hline B. Fixed cost & & & & 0.32 & 5.24 \\
\hline i. Housing cost & & & & 0.31 & 5.07 \\
\hline ii. Miscellaneous cost & & & & 0.01 & 0.16 \\
\hline C. Total cost $(A+B)$ & & & & 6.11 & 100.00 \\
\hline Returns: & & & & & \\
\hline i. Egg & Number & 1.08 & 28 & 30.35 & 89.17 \\
\hline iii. Inventory change & Tk. & & & 3.42 & 10.06 \\
\hline iv. Other purpose & Tk. & & & 0.26 & 0.77 \\
\hline D. Gross return & & & & 34.04 & 100.00 \\
\hline E. Gross margin (D-A) & & & & \multicolumn{2}{|c|}{28.25} \\
\hline F. Net return (D-C) & & & & \multicolumn{2}{|c|}{27.93} \\
\hline G. BCR, Undiscounted (D/C) & & & & \multicolumn{2}{|c|}{5.57} \\
\hline
\end{tabular}

Source: Field survey 2012.;

Note: Inventory change was calculated [Net change in inventory $=$ (Closing stock+Consumed/Gifted+Sold+ Died) - (Opening stock+Bought)] for one year.

Table 5. Employment generation through poultry rearing (working-hours/month)

\begin{tabular}{lccc}
\hline \multirow{2}{*}{ Scope of employment } & \multicolumn{3}{c}{ Family } \\
\cline { 2 - 4 } & Male & Female & Both \\
\hline Taking poultry in and out & 1.25 & 3.52 & 4.77 \\
Poultry shed cleaning & 2.45 & 5.21 & 5.16 \\
Scavenging & 0.59 & 2.87 & 3.46 \\
Veterinary care & 0.17 & 0.45 & 0.62 \\
Others & 0.14 & 0.25 & 0.39 \\
Total & 3.10 & 11.3 & 14.4 \\
\hline Average working hours/day & & 0.96 \\
& & & $(8.48)$ \\
\hline
\end{tabular}

Source: Field survey, 2012;

Note: Figures in the parenthesis indicate the number of poultry

\section{Sensitivity analysis}

Sensitivity analysis is a technique to assess the effects of adverse changes on a project. Reworking an analysis to see what happens under the changed circumstances is called sensitivity analysis (Gittinger 1984). A simple method of sensitivity analysis was used by Talukder and Uddin (2000) to vary the magnitude of the more important variables, single or in combination by a certain percentage and then to determine how sensitive the result is to such changes. Therefore, changes in the parameters of the model were made in the way that adversely affects the net benefit. For the simplicity of analysis in the study, following assumptions were considered: i) 10 percent increase in cost of inputs, price of output remaining unchanged; ii) 10 percent decrease in cost of inputs, price of output remaining unchanged; iii) 10 percent increase in output price, cost of inputs remaining unchanged; iv) 10 percent decrease in output price, cost of inputs remaining unchanged. The results of the sensitivity analysis considering the above assumptions are presented in Tables 7 and 8.

Table 6. Average annual income by sources

\begin{tabular}{lcc}
\hline Sources of income & Amount (Tk.) & Percentage \\
\hline i. Farm income & 125270.53 & 83.23 \\
Crop farming & 50544.17 & 33.58 \\
Fruits/vegetables & 5828.88 & 3.87 \\
production & 1058.33 & 0.70 \\
Goat rearing & 265.00 & 0.18 \\
Buffalo rearing & 6643.33 & 4.41 \\
Fish culture & 5428.89 & 3.61 \\
Labor selling & 43077.43 & 28.62 \\
Cattle rearing & 12424.50 & 8.25 \\
Poultry rearing & 24044.45 & 15.97 \\
ii. Non farm income & 10596.67 & 7.04 \\
Service & 8900.00 & 5.91 \\
Small business & 166.67 & 0.11 \\
Sewing & & \\
machine/tailoring & 1203.34 & 0.80 \\
Rickshaw/van & 3514.44 & 2.33 \\
pulling & 866.67 & 0.58 \\
Labor selling & 150518.32 & 100.00 \\
\hline iii. Others & & \\
\hline Total ( i + ii + iii ) &
\end{tabular}

Source: Field survey, 2012 
Uddin et al. (2013) Bang. J. Anim. Sci. 42 (1): 49- 56

Table 7. Change in costs and return of native poultry rearing with respect of assumptions I and II

\begin{tabular}{|c|c|c|c|c|c|}
\hline \multirow{2}{*}{ Particulars } & \multirow{2}{*}{$\begin{array}{l}\text { Original } \\
\text { amount } \\
\text { (Tk.) }\end{array}$} & \multicolumn{2}{|c|}{$\begin{array}{c}\text { Change in the value of } \\
\text { measures under }\end{array}$} & \multicolumn{2}{|c|}{$\begin{array}{c}\% \text { change in the value of } \\
\text { measures under }\end{array}$} \\
\hline & & $\underset{\mathrm{I}}{\text { Assumption }}$ & $\begin{array}{c}\text { Assumption } \\
\text { II }\end{array}$ & $\underset{I}{\text { Assumption }}$ & $\underset{\text { II }}{\text { Assumption }}$ \\
\hline A. Variable cost & 2113.35 & 2324.68 & 1902.02 & & \\
\hline B. Fixed cost & 116.80 & 128.48 & 105.12 & & \\
\hline C. Total cost $(A+B)$ & 2229.27 & 2453.16 & 2007.14 & & \\
\hline i. Milk/Egg & 11078.90 & 11078.90 & 11078.90 & & \\
\hline ii. Inventory change & 1250.00 & 1250.00 & 1250.00 & & \\
\hline iii. Other purposes & 95.60 & 95.60 & 95.60 & & \\
\hline D. Gross return $(\mathrm{i}+\mathrm{ii}+\mathrm{iii})$ & 12424.50 & 12424.50 & 12424.50 & & \\
\hline E. Gross margin & 10311.15 & 10099.82 & 10522.48 & 2.0 & 2.0 \\
\hline F. Net return & 10195.23 & 9971.34 & 10417.36 & 2.2 & 2.2 \\
\hline G. BCR & 5.57 & 5.06 & 6.19 & 9.2 & 11.1 \\
\hline
\end{tabular}

Source: Author's estimation, 2012;

Notes: Assumption I: 10 percent increase in cost of inputs, price of outputs remaining unchanged; Assumption II: 10 percent decrease in cost of inputs, price of output remaining unchanged

Table 8. Change in costs and return of poultry with respect of assumptions III and IV

\begin{tabular}{|c|c|c|c|c|c|}
\hline \multirow{2}{*}{ Particulars } & \multirow{2}{*}{$\begin{array}{c}\text { Original } \\
\text { amount (Tk.) }\end{array}$} & \multicolumn{2}{|c|}{$\begin{array}{c}\text { Change in the value of } \\
\text { measures under }\end{array}$} & \multicolumn{2}{|c|}{$\begin{array}{c}\% \text { change in the value of } \\
\text { measures under }\end{array}$} \\
\hline & & $\begin{array}{c}\text { Assumption } \\
\text { III }\end{array}$ & $\begin{array}{c}\text { Assumption } \\
\text { IV }\end{array}$ & $\begin{array}{c}\text { Assumption } \\
\text { III }\end{array}$ & $\begin{array}{c}\text { Assumption } \\
\text { IV }\end{array}$ \\
\hline A. Variable cost & 2113.35 & 2113.35 & 2113.35 & & \\
\hline B. Fixed cost & 116.80 & 116.80 & 116.80 & & \\
\hline C. Total cost $(A+B)$ & 2229.27 & 2229.27 & 2229.27 & & \\
\hline i. Milk/Egg & 11078.90 & 12186.79 & 9971.01 & & \\
\hline ii. Inventory change & 1250.00 & 1250.00 & 1125 & & \\
\hline iii. Other purposes & 95.60 & 95.60 & 86.04 & & \\
\hline D. Gross return $(\mathrm{i}+\mathrm{ii}+\mathrm{ii})$ & 12424.50 & 13532.39 & 11182.05 & & \\
\hline E. Gross margin & 10311.15 & 11419.04 & 9068.7 & 11.0 & 12.0 \\
\hline F. Net return & 10195.23 & 11303.12 & 8952.78 & 11.1 & 12.2 \\
\hline G. BCR & 5.57 & 6.07 & 5.02 & 20.0 & 9.9 \\
\hline
\end{tabular}

Source: Author's estimation, 2012;

Notes: Assumption III: 10 percent increase in outputs price, cost of inputs remaining unchanged; Assumption IV: 10 percent decrease in output price, cost of inputs remaining unchanged

Table 8 shows that 10 percent increase in output price enhanced gross margin, net return and BCR by 11.0 percent, 11.1 percent and 20.0 percent, respectively and 10 percent decrease in output price declined gross margin, net return and BCR by 12.0 percent, 12.2 percent and 9.9 percent, respectively for native poultry rearing.

\section{Production function analysis}

Multiple Regression model was used for estimating the coefficient of income generated from rearing native poultry. Ten variables were identified as key contributor to the production process. The results of estimation of the model for native poultry rearing are presented in Table 9.

\section{I nterpretation of the estimated model}

It was found from the production function analysis that year of schooling, income from other sources, training and vaccine and medication were significantly affected gross returns of native poultry production.

Year of schooling $\left(X_{2}\right)$ : It is evident from Table 9 that the coefficient of the year of schooling was estimated as 0.148 for poultry which was significant at 1 percent probability level. Thus, there was a positive relationship between year of schooling of the respondents and gross return. That is, 1 percent increase in the year of schooling of the respondents, on an average, led to 0.148 percent increase in gross return for poultry rearing farmers, holding other variables constant. 


\section{Economics of native poultry rearing}

Income from other sources $\left(X_{8}\right)$ : In case of income from other sources, the coefficient was 0.062 for the sampled farmers, which was significant at 10 percent probability level. Thus, there was a positive relationship between income from other sources and gross return. That is, 1 percent increase in income from other sources, on an average, led to 0.062 percent increase in gross return for poultry rearing, holding other variables unchanged.

Table 9. Estimated values of coefficients and related statistics of Multiple Regression model

\begin{tabular}{|c|c|c|}
\hline Explanatory variables & $\begin{array}{l}\text { Estimated } \\
\text { coefficient }\end{array}$ & t-value \\
\hline Intercept & $\begin{array}{c}4.963 \\
(0.592)\end{array}$ & 8.383 \\
\hline $\begin{array}{l}\text { Age of the } \\
\text { respondents }\left(X_{1}\right)\end{array}$ & $\begin{array}{c}0.093 \\
(0.126)\end{array}$ & 0.738 \\
\hline $\begin{array}{l}\text { Year of schooling } \\
\left(X_{2}\right)\end{array}$ & $\begin{array}{l}0.148^{* * *} \\
(0.049)\end{array}$ & 3.020 \\
\hline Family size $\left(X_{3}\right)$ & $\begin{array}{c}0.089 \\
(0.143)\end{array}$ & 0.622 \\
\hline Land holding $\left(\mathrm{X}_{4}\right)$ & $\begin{array}{c}0.087 \\
(0.134)\end{array}$ & 0.649 \\
\hline $\begin{array}{l}\text { No. of livestock } \\
\text { enterprises }\left(X_{5}\right)\end{array}$ & $\begin{array}{c}0.380 \\
(0.686)\end{array}$ & 0.554 \\
\hline Working hours $\left(X_{6}\right)$ & $\begin{array}{c}0.174 \\
(0.194)\end{array}$ & 0.897 \\
\hline Rearing cost $\left(X_{7}\right)$ & $\begin{array}{l}-0.082 \\
(0.144)\end{array}$ & -0.569 \\
\hline $\begin{array}{l}\text { Income from other } \\
\text { sources }\left(X_{8}\right)\end{array}$ & $\begin{array}{c}0.062^{*} \\
(0.025)\end{array}$ & 2.480 \\
\hline Training $\left(D_{1}\right)$ & $\begin{array}{l}0.179^{* *} \\
(0.080)\end{array}$ & 2.238 \\
\hline $\begin{array}{l}\text { Vaccine and } \\
\text { medication }\left(D_{2}\right)\end{array}$ & $\begin{array}{l}0.282^{* *} \\
(0.120)\end{array}$ & 2.357 \\
\hline $\mathrm{R}^{2}$ & \multicolumn{2}{|c|}{0.757} \\
\hline $\bar{R}^{2}$ & \multicolumn{2}{|c|}{0.710} \\
\hline F-Value & \multicolumn{2}{|c|}{$4.724^{* * *}$} \\
\hline Returns to scale $\left(\Sigma b_{i}\right)$ & \multicolumn{2}{|c|}{1.412} \\
\hline
\end{tabular}

Source: Author's estimation, 2012;

Note: Figures in the parentheses indicate standard error; ***, $\mathrm{p}<0.01 ; * *, \mathrm{p}<0.05 ; *, \mathrm{p}<0.1$

Training of the respondents $\left(D_{1}\right)$ : The estimated value of the coefficient of training was 0.179 for poultry rearing farmers which was significant at 5 percent probability level. This implies that the respondents who received training got 17.90 percent more income than the respondents who did not receive training.

Vaccine and medication $\left(D_{2}\right)$ : The estimated value of the coefficient of vaccine and medication was 0.282 which was significant at 5 percent probability level. This implies that the respondents who used vaccine and medication obtained 28.20 percent more income than the respondents who did not use vaccine and medication

Value of $\mathrm{R}^{2}$ : The estimated value of the coefficient of multiple determination, $\mathrm{R}^{2}$ of the model was 0.757 , which indicated that about 75 percent of the total variation in gross return under poultry rearing has been explained by the variables included in the model. In other words, 25 percent of the total variation in the gross return is unexplained due to the variables which were not included in the model.

Value of adjusted $\bar{R}^{2}$ : The estimated value of the adjusted $\bar{R}^{2}$ of the model was 0.710 for poultry rearing farmers (Table 9). Here, the term adjusted means adjusted for the degrees of freedom (Gujarati, 2003). This value indicated that about 71 percent of the total variation in gross return under poultry has been explained by the variables included in the model considering the degrees of freedom.

F-value: The F-statistic was estimated for overall significance of the estimated model. The F-values of the model derived was 4.724. This value was highly significant at 1 percent probability level implying that all the explanatory variables included in the model were important for explaining the variation in gross return for poultry rearing.

Returns to scale $\left(\Sigma b_{i}\right)$ : The value of returns to scale was estimated as 1.412 , which indicates that if all the inputs specified in the model were increased by 1 percent, the gross return of poultry rearing would increase by 1.412 percent.

\section{Resource use efficiency}

Marginal value product (MVP) of any resource depends on the quantity of it already being used and on the level of the other resources with which it is combined in the production process (Heady and Dillon, 2003). (MVP) is obtained by taking resources such as year of schooling $\left(X_{2}\right)$, land holding of the respondents $\left(X_{4}\right)$, number of livestock enterprises $\left(X_{5}\right)$, working hours $\left(X_{6}\right)$, rearing cost $\left(X_{7}\right)$ and income from other sources $\left(\mathrm{X}_{8}\right)$ as well as return $(\mathrm{Y})$ at their geometric mean (Dhawon and Bansal, 1977). The estimated MVPs of different inputs are presented in Table 10. 


$$
\operatorname{MVP}\left(X_{i}\right)=b_{i} \frac{\bar{Y}(G M)}{\bar{X}_{i}(G M)}
$$

The table shows that the ratios of marginal value product (MVP) and marginal factor cost (MFC) for the variables of year of schooling $\left(X_{2}\right)$, land holding of the respondents $\left(X_{4}\right)$, number of livestock enterprises $\left(X_{5}\right)$ and income from other sources $\left(X_{8}\right)$ were greater than unity indicating that more return may be obtained by increasing the use of these resources. But this ratio for rearing cost $\left(X_{7}\right)$ was negative which indicates the excessive use of this input perhaps due to easy availability of home supplied labour. Hence, this input use should be reduced by the poultry rearing farmers.

Table 10. Marginal value products of different resources

\begin{tabular}{lccccc}
\hline Variables & $\begin{array}{c}\text { Geometric } \\
\text { Mean } \\
\text { (Antilog) }\end{array}$ & $\begin{array}{c}\text { Coeffi- } \\
\text { cients }\end{array}$ & MVPs & MFC & MVP/MFC \\
\hline $\begin{array}{l}\text { Gross return } \\
\text { (Y) }\end{array}$ & 23.88 & & & & \\
$\begin{array}{l}\text { Year of } \\
\text { schooling } \\
\left(X_{2}\right)\end{array}$ & 0.07 & 0.148 & 0.19 & 1 & 2.19 \\
$\begin{array}{l}\text { Land holding } \\
\left(X_{4}\right)\end{array}$ & 0.09 & 0.087 & 0.07 & 1 & 2.07 \\
$\begin{array}{l}\text { No. of } \\
\text { livestock } \\
\text { enterprises } \\
\left(X_{5}\right)\end{array}$ & 0.28 & 0.38 & 0.80 & 1 & 2.80 \\
$\begin{array}{l}\text { Working } \\
\text { hours }\left(X_{6}\right)\end{array}$ & 0.16 & 0.174 & 0.14 & 1 & 3.14 \\
$\begin{array}{l}\text { Rearing cost } \\
\left(X_{7}\right)\end{array}$ & 0.03 & -0.082 & -0.06 & 1 & -7.60 \\
$\begin{array}{l}\text { Income from } \\
\text { other sources } \\
\left(X_{8}\right)\end{array}$ & 0.08 & 0.062 & 0.07 & 1 & 6.07 \\
\hline
\end{tabular}

Source: Author's estimation, 2012;

Note: MVP, marginal value product; MFC, marginal factor cost

It was observed that the ratios of MVP and MFC of all the inputs were not positive. These inequalities indicate that the farmers in the study area have failed to show their efficiency in using all the resources. It is, therefore, concluded that poultry rearing farmers in the study area have scope to attain full efficiency by reallocating the resources.

\section{Constraints and opportunities in native poultry rearing}

Limited coverage of veterinary services, inadequate capital, high price of poultry feed, lack of scientific knowledge, restriction of breeds etc. are the main problems faced by the poultry rearing farmers. They also provided some suggestions to overcome the constraints such as provision of training facilities, expansion of credit facilities, supply of adequate feed at subsidized price, facility of proper veterinary care and health services, etc

\section{Conclusion}

Native poultry rearing in coastal areas have been practiced for a long time at a small scale for multipurpose activities. The study revealed that the benefit cost ratio from native poultry rearing was 5.57, which indicated that poultry rearing is profitable venture that enhanced farms monthly net income by 58 percent. The more benefit could still be harvested through training to the farmers on improved process of poultry bird rearing. The sensitivity analysis shows that the gross margins and benefit cost ratios were strongly influenced by the factors such as the poultry inventory, cost of inputs and price of outputs. The production function analysis indicates that the important inputs for poultry rearing are training of the respondents regarding poultry bird's health management, timely vaccination and medication along with adequate delivery of vaccines to the keepers. Most of the regression coefficients, i.e., year of schooling, income from other sources, training of the respondents, vaccine and medication etc. had positive and statistically significant value for poultry rearers with higher MVPs which indicates that farmers can increase gross returns by increasing the use of these resources. Though now-a-days native poultry farmers are facing some problems but the higher returns from poultry rearing will depend upon successfully overcoming such constraints. Finally, it may be concluded that subsistence poultry rearing could be encouraged in Bangladesh as an effective means for income generations and employment creation, especially for women in the coastal regions which will ultimately reduce poverty and improve overall livelihood.

\section{Acknowledgements}

The authors are greateful to the authority of Bangladesh Livestock Research Institute, Savar, Dhaka for providing logistic and financial support to conduct this study. The authors also express cordial thanks and sincere gratitude to the farmers involved in poultry rearing in the coastal regions who provided valuable information. 


\section{Economics of native poultry rearing}

\section{References}

BBS (2009). Statistical Yearbook of Bangladesh, Bangladesh Bureau of Statistics, Statistics Division, Ministry of Planning, Government of the Peoples' Republic of Bangladesh, Dhaka.

BER (2011). Bangladesh Economic Review, Economic Advisory Section, Department of Finance, Ministry of Finance, Bangladesh.

Dhawon KC, Bansal PK (1977). Rationality of the use of various factors of production on different sizes of farm in the Panjab. Indian Journal of Agricultural Economics, 23: 121130.

Gittinger JP (1984). Economic Analysis of Agricultural Projects, Second Edition, EDI series in Economic Development.

Gujarati DN (2003). Basic Econometrics. McGrawHill, New York.

Heady EO Dillon JL (2004). Agricultural Production Functions, USA, I owa State University press, Ames, P. 73.

HIES (2010). Preliminary Report on Household Income and Expenditure Survey, Bureau of
Statistics Division, Ministry of Planning, Government of the peoples' Republic of Bangladesh, Dhaka

Miah MMU (2010). Assessing Long-term Impacts of Vulnerabilities on Crop Production Due to Climate Change in the Coastal Areas of Bangladesh. Final Report PR No. 10/08. Bangladesh Center for Advanced Studies. National Food Policy Capacity Strengthening Program.

Rahman MM, Khan MJ, Chowdhury SD, Akbar MA (2009). Duck Rearing System in Southern Coastal Districts of Bangladesh. Bangladesh J ournal of Animal Science, 38: 132-141.

SFYP (The Second Five Year Plan) (2009). Planning Commission, Ministry of Planning, Government of the Peoples' Republic of Bangladesh, Dhaka.

Talukder RK, Uddin MT (2000). Economics of Milk Production in Bangladesh. A contract research project report, Bureau of Socioeconomic Research and Training, Bangladesh Agricultural University, Mymensingh, Bangladesh. 